\title{
Editorial
}

\section{Times of Upheaval and Uncertainty: The Year in Review}

\author{
Maria Lorena Cook, Cornell University, USA \\ Madhumita Dutta, The Ohio State University, USA \\ Alexander Gallas, University of Kassel, Germany \\ Jörg Nowak, Independent Researcher, Brazil \\ Ben Scully, University of the Witwaterstand, South Africa
}

"We live in times of upheaval and uncertainty...." In the age of COVID-19, it has become practically obligatory for all of us to include such a phrase in our communications. But we wrote this in our January 2020 editorial, a couple of months before we knew that a global pandemic would turn our world inside out. At the time, we noted such developments as the rise of the far right in many nations, the global climate crisis, increasing precarity, protests against rising poverty and inequality, and more. We spoke of "system crisis".

We had not intended to write another editorial for our second issue in 2020, but by May it was clear that the severity of the global health and economic crisis was changing everything. We had to address it, even if at that point we had mostly questions. Our editorial, Global Labour in the Pandemic: Notes for an Emerging Agenda, tried to view the issues we identified in January through the lens of the pandemic and to start a debate on how it is impacting labour. We noted the ways in which some categories of workers gained visibility while others receded from view, and how that visibility shifted over time; how the pandemic spread was linked to the living and working conditions of workers; how class, race and gender relations meant that different groups of workers were affected by the pandemic in very different ways; the implications of digitalisation for worker control; the political authoritarianism that emerged in some countries; the unequal impacts of both health and economic crises within countries and across the globe.

We also raised the prospect that these crises would produce opportunities, as previously "radical" policy ideas might be considered, new forms of resistance and organisation would emerge, and new leaders step forth. Shortly after the publication of the May editorial, we witnessed the formation of one of the most significant protest movement to emerge in decades: the Black Lives Matter protests and the broad societal reckoning with systemic racism that began with George Floyd's murder at the hands of police in Minneapolis in May 2020. These protests saw echoes not just across the United States but around the world, with protesters across six continents connecting the events in Minnesota to local experiences of racist violence and police brutality.

In times of deep crisis, the mobilisations create a much-needed space to demand systemic change and discuss political alternatives to a global social order characterised by deep (and rapidly deepening) inequalities. Despite the obstacles to mobilisation presented by the pandemic, popular uprisings continue to spring up: protests against police violence in Colombia have gripped the country for weeks; in Iraq and Iran mobilisations are occurring in parts of society and across industrial sectors; and resistance against authoritarian regimes in Thailand, Belarus and Libya 
shows no signs of abating. After a mega-blast in the port of Beirut in August 2020 that killed hundreds and rendered 300000 people homeless, protests against the political class grew stronger. And as we write this, youth across the globe are engaging in a climate strike.

Meanwhile, the International Labour Organization (ILO, 2020) reports that workers worldwide have lost an average of 10 per cent of their income since the pandemic began, and there are reports that an increasing number of "essential" workers are suffering from burnout (Sainato, 2020). Several major labour struggles have emerged in this context. In the United States, graduate students at both public and private universities are organising and winning their right to unionise, demanding better working conditions, contracts and pay (Marcus, 2020). In Brazil, 100000 postal workers have held out for weeks on a strike against privatisation and a 40 per cent cut in pay. In Germany, a wave of short strikes is taking place across the public sector, with workers linking their demands for higher wages and a reduction of the longer work hours in the East of the country with the extra efforts they have made to contain the pandemic.

This year also marks the GLJ's tenth anniversary. To commemorate this milestone, we introduced special features, such as social media posts of past articles from our archives, and invited Global Issues pieces to address topical and methodological gaps in labour studies. Throughout the year, those authors who graciously accepted our invitations to contribute have produced pieces that pushed forward our thinking about global labour. Several addressed the impacts of the COVID-19 crisis and the emergence of protests around the world.

The anniversary year Global Issues series began in our January issue with an analysis by Kirsten Sehnbruch and Sofia Donoso of the protests against systemic inequality that rocked Chile in 2019, which in many ways foreshadowed the police violence and spontaneous protest leadership that we would come to see in the United States during the anti-racism protests in 2020.

Appearing in our May issue, Sefika Kumral and Sahan Savas Karatașli examine the expansion of the populist radical right. They urge us to move away from an exclusive focus on the United States and Western Europe in analysing right-wing popular mobilisation in response to capitalist crisis; they locate the emergence of this populist reaction in the 1970s, far earlier than most analyses. Kumral and Karatassli call for expanding the spatial and temporal horizons of our analysis and to reconsider populist politics in different parts of the world as part of an interconnected whole. Alessandra Mezzadri also calls for de-centring capitalism in the West to focus on the ways in which capitalism and labour have evolved in the Global South, which is to say, in much of the world. She notes that, contrary to the way researchers in the North have traditionally treated informality, informal labour is the primary mode of employment at the global level. Her intervention centres on the role of female labour in social reproduction and labour informalisation.

Archana Prasad continues the discussion on informal labour via her examination of the precarious livelihoods of informal workers in Delhi, many of them migrants, who are also victims of violence as a result of the anti-Muslim Citizenship Act, perpetuated by a government engaged in a "neo-liberal majoritarian project." Vishwas Satgar turns to the impact of government responses to COVID-19, in this case in South Africa, where he calls attention to the need for a basic income grant as a way to mitigate the socio-economic impacts of the lockdown, one of the most restrictive on the planet in its early stages.

Phoebe Moore explores a topic which has only become more relevant in the pandemic: the role of technology and work, in particular the use of artificial intelligence in the workplace and the increased surveillance of the worker that digitalisation makes possible. Her focus is on the "smart worker" in this environment: the human at work. Meanwhile, Marcel van der Linden and Jan Breman adopt a broad lens with their analysis of trends in contemporary capitalism. They 
identify a rise in mercantile and financial capital, together with a growing proletarianisation, in a context of pauperisation, inequality, declining union presence and the growing importance of labour migration.

In this issue we have four more contributions to the tenth anniversary Global Issues series. Peter Evans argues that the pandemic has shown the degree to which "capability-enhancing" service workers such as nurses and teachers are central, not only to promoting the well-being of society, but also to an anti-capitalist class politics that can "engage the general problem of capitalism: misallocation of societal resources resulting in mounting unmet needs and the underfunding of the jobs necessary to meet those needs". Maurizio Atzeni focuses on how precarity and the increasing centrality of reproduction mean that organisations beyond trade unions should also be considered central to working-class struggles. He critiques what he calls the fetishisation of trade unions as a form and highlights some recent work that corrects this error.

Rohini Hensman details the unequal impact of the pandemic and lockdown measures on informal workers in India. She argues that the shocking treatment of informal workers represents a "three-fold denial" of their rights as workers, citizens and human beings. Rina Agarwala argues that the hegemony of the free-market ideology that has reigned for the past few decades is now clearly on the wane. However, she warns that the competing ideas that might replace free-market fundamentalism could just as easily come from capital or right-wing politics as from labour or the left. In light of this, she encourages global labour scholars to pay more attention to both elites and the political right in order to critically engage the ideas they offer about the current crisis.

In our January editorial we also identified ways in which we might do more to ensure that the GLJ remain a global labour journal, via greater representation from underrepresented authors and regions, and expanded accessibility to non-English speaking researchers. The articles we have published in this past year have spanned a range of geographical locations and topics: from India to Australia, Turkey to Germany, and South Korea to Canada; from care work and meatpacking to engineers, miners and retail workers; from global value chains and trade agreements to suicide protest, migrant labour and racism. If we include our Global Issues pieces, we find a greater gender balance among authors, as well as more of a focus on the Global South or on topics that mostly span the Global South.

Our Book Review section continues to feature books about workers and topics from a wide range of countries, among them Indonesia, China, Nepal, Thailand, South Africa and Brazil, as well as topics that span the globe. In our ongoing efforts to expand the review of books published in languages other than English, one of these books is in French and another in German. The challenges we set out in January - to improve the number of articles that address issues in the Global South and the number of authors from the Global South - remain relevant, and with your help we will continue to work toward a greater representation of diverse regions, topics and authors in the coming years.

As we close this final issue of our tenth anniversary year, just over one million people worldwide have died in the coronavirus pandemic, a safe and effective vaccine remains months if not years away, partial re-openings have led to renewed lockdowns and prolonged economic suffering in some countries, and United Nations agencies forecast widespread famine. Across the globe, hurricanes, wildfires, droughts and floods are a reminder that we also face a serious ecological crisis. However, all is not lost. As we have seen, these crises are also spawning widespread protest and resistance, which contain in themselves the possibility of change.

As a journal, we will continue to put work and workers at the centre of our efforts to make sense of these and other global developments. We invite our readers to submit contributions that engage with the questions raised in our editorials and Global Issues series, and we especially want 
to thank everyone who has collaborated with the GLJ in this most difficult of times. We look forward to working with you as we enter our second decade.

\section{REFERENCES}

International Labour Organization (ILO) (2020) COVID-19 Leads to Massive Labour Income Losses Worldwide, Press Release, 23 September 2020.: https://www.ilo.org/global/about-theilo/newsroom/news/WCMS 755875/lang--en/index.htm (last accessed 26 September 2020).

Marcus, Jon (2020) Amid Pandemic, Graduate Student Workers are Winning Long-sought Contracts. Washington Post, July 19.: https://www.washingtonpost.com/education/2020/07/19/grad-studentunions-pandemic (last accessed 26 September 2020).

Sainato, M. (2020) "I Cry Before Work": US Essential Workers Burned Out Amid Pandemic. The Guardian, 23 September 2020. https://www.theguardian.com/us-news/2020/sep/23/us-essentialworkers-coronavirus-burnout-stress (last accessed 26 September 2020). 